\title{
Erratum to: Invited commentary on Modified classification of surgical meshes for hernia repair, U. Klinge, B. Klosterhalfen
}

\author{
A. C. de Beaux
}

Published online: 21 August 2012

(C) Springer-Verlag 2012

Erratum to: Hernia (2012) 16:259

DOI 10.1007/s10029-012-0922-5

In the article "Invited commentary on HERN-D-1100301R3," an error was introduced by the publisher. The correct title should read "Invited commentary on Modified classification of surgical meshes for hernia repair, U. Klinge, B. Klosterhalfen.”

The publisher apologizes for this error.

The online version of the original article can be found under doi:10.1007/s10029-012-0922-5.

A. C. de Beaux ( $\square)$

Royal Infirmary of Edinburgh, Edinburgh EH16 4SA, UK

e-mail: adebeaux@doctors.org.uk 